\title{
A guide to best practices for the transition from ipv4 to ipv6
}

Lennart Enrique Madera V., MSc. / lennartmadera@gmail.com

Mario Alejandro Roa G., MSc. / mario.roa11@gmail.com

Emcali EICE ESP, Cali-Colombia

Juan C. Cuéllar Q. / jcuellar@icesi.edu.co

Universidad Icesi, Cali-Colombia

ABSTRACT This article presents a proposal for a guide to best practices to support Information Technology [T] areas in the planning and implementation of the transition of their infrastructure and technology services to IPv6 protocol. For this purpose an analysis of references was done to identify the problem, comprehend the state of the art; the current state of advance in the migration to IPv6 and its implementation worldwide; the state of the art of technology in the regions where it is a key factor and the process that these regions have developed to explore and implement the transition from IPv4 to IPv6, and as an analysis of the manner in which their governments assumed this transition; the identification of how the processes of the model of best practices for IT, ITIL v.3 can support the transition; and the existing mechanisms of technological transition from IPv4 to IPv6 according to two scenarios: with and without IPv4 and IPv6 coexisting.

KEYWORDS IPv6 (Internet Protocol Version 6); IPv4 (Internet Protocol Version 4); transition; ITIL; Internet; best practices.

Guía de buenas prácticas para la transición de ipv4 a ipv6

RESUMEN Este artículo presenta una propuesta de guía de buenas prácticas para asistir a las áreas de Tecnología de la Información [T] en los procesos de planeación e implementación de la transición de sus servicios de infraestructura y tecnología hacia el protocolo IPv6. Se realizó un análisis de referencias para la identificación del problema y un exhaustivo estudio del estado del arte, particularmente se puntualizó en el estado actual del avance en la migración hacia IPv6 y su implementación a nivel global, en el estado actual de la tecnología en las regiones donde este protocolo es un factor clave y en el proceso que esas regiones han desarrollado para la materialización de la transición. También se presentan los resultados del análisis de los métodos llevados a cabo por los gobiernos para materializar dicha transición, la identificación de cómo los procesos del modelo de buenas prácticas para TI de ITIL ${ }^{\circledR}$ pueden soportar esta transición y los mecanismos existentes de transición tecnológica de IPv4 a IPv6 bajo dos escenarios: con y sin coexistencia de ambos protocolos.

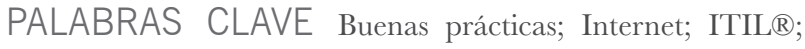
IPv4 (Protocolo de Internet versión 4); IPv6 (Protocolo de Internet versión 6); Transición.
Um guia para as melhores práticas para a transição do IPv4 para o IPv6

RESUMO Este artigo apresenta uma proposta de um guia de melhores práticas para apoiar a área de Tecnologia da Informação [T] no planejamento e implementação do processo de transição dos seus serviços de infraestrutura e tecnologia para o protocolo IPv6. Para este efeito foi realizada uma análise de referências para identificar o problema, compreender o estado da arte; o estado atual de avanço na migração para o IPv6 e a sua aplicação a nível mundial; o estado da arte da tecnologia nas regiões em que é um factor chave e o processo que estas regiões têm desenvolvido para explorar e implementar a transição do IPv4 para o IPv6, e uma análise da maneira pela qual os seus governos assumiram esta transição; a identificação da forma em que os processos do modelo de melhores práticas para TI, ITIL v.3 poderiam apoiar a transição; e os mecanismos existentes de transição tecnológica do IPv4 para IPv6 de acordo com dois cenários: com e sem coexistência de IPv4 e IPv6.

PALAVRAS-CHAVE IPv6 (Internet Protocol versão 6); IPv4 (Internet Protocol versão 4); transição; ITIL; Internet; melhores práticas. 


\section{Introduction}

The area of Information Technology (IT) plays an important role in the generation of value for an organization's client base and in the optimization of business processes through the implementation of technological solutions that are aligned with the strategic objectives, thereby generating a competitive advantage for the organization.

These technological solutions use the Internet Protocol (IP) for information exchange. Due to the exhausting of IPv4 addresses it is necessary for organizations to plan and execute a process of transition towards IPv6.

Although in the short term organizations can continue operating with IPv4 without major implications, there will come a time when the migration to IPv6 will become essential. This need will be driven by service providers, strategic allies and internal and external clients, either because of their demand for connection or because their own applications and services will have migrated to IPv6.

In Latin America, the transition to IPv6 hasn't happened on a massive scale because of an absence of awareness about the topic and the lack of clarity regarding the strategies that should be adopted by an organization to face this process, which should consider aspects such as those of a technological, educational and organizational character (Lanic, 2014).

Given the exhaustion of $\mathrm{IPv}_{4}$ addresses, the need to make a transition from IPv4 to IPv6 arises, and if the area of Information Technology within an organization isn't prepared for this transition, it can result in a high impact on the service it provides (Palet, 2011).

With the passage of time, there is technological advance, more mobility, increased use of collaboration tools and an improvement in processes, all of which generate value for the organization and augment the number of users and connected devices. Consequently, there is a need for higher capacity in the connection to the Internet, and it is here that IPv6 becomes indispensable.

With the above discussion in mind, we conclude that there is a need to augment the capacity of addresses transiting to IPv6, but there is no document or guide to best practices for such a transition to take place with adequate planning and implementation.

In spite of the Colombian government issuing guidelines and policies for the adoption of IPv6, no guide to best practices, which takes into account technological, cultural, administrative and managerial factors, exists.

\section{Introducción}

El área de Tecnologías de la Información [TI] juega un papel importante en la generación de valor para las organizaciones basadas en sus clientes y en la optimización de procesos de negocio a través de la implementación de soluciones tecnológicas alineadas con los objetivos estratégicos de la misma; generando así ventajas competitivas para la empresa. Dichas soluciones utilizan el Protocolo de Internet [IP: Internet Protocol] para el intercambio de información.

Debido al agotamiento de direcciones IPv4, las empresas deben planear y ejecutar procesos de transición hacia IPv6. Aunque en el corto plazo las organizaciones pueden continuar operando bajo el protocolo IPv4 sin mayores implicaciones, lo más seguro es que llegará el momento en que la migración hacia IPv6 sea indispensable. Lo anterior será impulsado por proveedores de servicio, aliados estratégicos y clientes internos y externos, ya sea por la demanda de conexiones o por la necesidad de migración de sus servicios y aplicaciones hacia IPv6.

En Latinoamérica, la transición hacia IPv6 no ha sido masiva, puesto que existe una falta de conocimiento acerca del tema y poca claridad en cuanto a las estrategias que las organizaciones deberían adoptar para afrontar este proceso. Algunos aspectos a tener en cuenta por parte de las compañías de telecomunicaciones están relacionados con los ámbitos tecnológicos, educacionales y de carácter organizacional propio (Lanic, 2014).

$\mathrm{El}$ agotamiento de las direcciones $\mathrm{IPv} 4$ fortalece la necesidad de la transición de IPv4 a IPv6, por lo que, si el área de TI en una organización no está preparada para dicha transición, el resultado puede representar alto impacto en los servicios que presta (Palet, 2011).

El avance tecnológico y en la movilidad, junto con el incremento en el uso de herramientas colaborativas para diversos procesos, que aumenta con el paso del tiempo, llevan a la generación de valor para la empresa; por consiguiente, se incrementa el número de usuarios y de dispositivos conectados, por lo que se requiere mayor capacidad en la conexión a internet, es ahí donde IPv6 juega un papel importante.

De lo anterior se concluye que existe la necesidad de incrementar la capacidad de migración de las organizaciones hacia direcciones IPv6, sin embargo, no existen documentos o guías de buenas prácticas para que dicha transición sea ejecutada con niveles adecuados de planeación e implementación. El gobierno colombiano está actualmente expidiendo normas y regulaciones para la adopción de IPv6, pero debe tenerse en cuenta que no existe en la actualidad una guía de buenas prácticas que tenga en cuenta factores tecnológicos, culturales, administrativos y directivos.

Este artículo, tomando en cuenta ese vacío, presenta una 
guía de buenas prácticas para la transición de $\operatorname{IPv} 4$ a $\operatorname{IPv} 6$ desde la perspectiva del área de TI de una organización. Esta guía servirá como contribución hacia un mejor entendimiento de la necesidad de implementar IPv6 en organizaciones en Colombia y en el resto de Sudamérica. También presenta conceptos relacionados con la adopción y preparación de tal transición para minimizar el impacto de esta actividad en la organización.

El documento se organiza de la siguiente manera: la sección II trata sobre la metodología y el análisis de referencias consultadas para la preparación de la guía; en la sección III se presenta la guía como tal, además de la identificación de prácticas para empezar el proceso de migración hacia IPv6, mientras que la sección IV presenta la validación de la guía propuesta a través de la opinión de expertos y discute los resultados obtenidos; finalmente se presentan las conclusiones que arroja el desarrollo del trabajo.

II. Metodología utilizada para proponer la guía de buenas prácticas

Para la creación de una guía con buenas prácticas para la transición de IPv4 a IPv6 se llevó a cabo un análisis de los trabajos descritos por Lacnic (2014) y Cicileo et al., (2009). Este análisis se hizo para identificar el problema, comprender el estado del arte en la implementación de IPv6 y aprender de experiencias satisfactorias. Los principales aspectos considerados fueron:

- el protocolo IPv6 y las entidades que soportan la transición a nivel global (Lacnic, 2014);

- el estado actual del avance en la migración hacia IPv6 y su implementación a nivel global (Lacnic, 2014).

- el estado del arte de la tecnología en regiones donde IPv6 presenta un valor relevante y el proceso que dichas regiones han desarrollado para explorar e implementar la transición, con énfasis en España, Australia y Estados Unidos, países que se destacan (Gobierno de España..., 2011; Internet Society of Australia, 2009; CIO Council, 2012).

- el análisis de la manera cómo los gobiernos de los países mencionadas asumieron la transición, además de cómo se implementó la dirección y gestión de estos gobiernos en el proceso de transición; los ejemplos mencionados establecieron los parámetros para un proceso de migración exitoso.

- la identificación de los procesos del modelo ITIL $^{\circledR}$ de mejores prácticas para TI y cómo puede soportar la transición.

- los mecanismos existentes de transición tecnológica de IPv4 a IPv6 dados dos escenarios que pueden surgir en una organización: el primero, donde toda la infraestructura esté configurada con IPv6 y el segundo, donde coexistan IPv4 e IPv6 (Madera \& Roa, 2014).

Durante la construcción de la guía se utilizaron las buenas prácticas de TI y de ITIL ${ }^{\circledR}$ como soporte, especialmente en
Therefore, this article will present a guide to best practices for the transition from IPv4 to IPv6 from the perspective of the Information Technology area of an organization. Such a guide will make a contribution towards understanding the necessity to implement IPv6 in organizations in Colombia and the rest of South America. The guide will also advise about the adoption of and preparation for such a transition, thereby minimizing the impact upon the organization's activity.

The article is organized in the following manner: section II deals with the methodology and an analysis of the references consulted to propose the guide. In section III, we present the proposed guide and identify the practices to undertake in the process of migration to IPv6. In section IV, we present the validation of the proposed guide through expert opinion and the results obtained. Finally, conclusions are discussed and references are disclosed.

\section{Methodology utilized to propose the guide to best practices}

For the purpose of creating a guide to best practices for the transition from IPv4 to IPv6, an analysis of references (Lacnic, 2014; Cicileo et al., 2009) was undertaken. This analysis was done to identify the problem, comprehend the state of the art in the implementation of IPv6 and learn from successful experiences. The main aspects considered were:

- IPv6 and the entities that support the transition worldwide (Lacnic, 2014);

- the current state of advance in the migration to IPv6 and its implementation worldwide (Lacnic, 2014);

- the state of the art of technology in the regions where it is a very relevant factor and the process that these regions have developed to explore and implement the transition from IPv4 to IPv6; Spain, Australia and the United States of America stood out above the rest (Gobierno de España..., 2011; Internet Society of Australia, 2009; CIO Council, 2012);

- an analysis of the manner in which the governments of these regions assumed the transition and how this study of successful cases was used for the purpose of creating the proposed guide. The guidance and management of the governments in the process of transition was outspoken; they were the ones who established the parameters for successful processes of migration;

- identification of the processes of the model of best practices for IT, ITIL version 3, and how these can support the transition; and 
- existing mechanisms of technological transition from IPv4 to IPv6 according to two scenarios that can arise in an organization: one where everything is solely configured in IPv6 and the other where IPv4 and IPv6 coexist (Madera \& Roa, 2014).

During the construction of the guide, the best practices of IT and ITIL version 3 were used as support, especially in service transition management, change management and configuration management.

Based on the scenarios of migration defined, it must be determined whether a total transition to IPv6 should be made or a coexistence of both protocols (IPv4 and IPv6) is more appropriate for the organization. However, in the latter case, there is an underlying premise that the entire infrastructure must finally be implemented in IPv6. A diagnosis of the infrastructure and its meticulous analysis is fundamental.

\section{The proposed guide}

The proposed guide to best practices is based on seven practices ordered in a sequential manner and designed with a template with the following aspects: purpose; description; input; process (technological, educational and political dimensions); and output.

These are the seven practices that compound the guide of best practices for the transition to IPv6:

- Practice 1: Planning of the transition project.

- Practice 2: Definition of policies.

- Practice 3: Gathering of information.

- Practice 4: Implementation plan of the transition to IPv6.

- Practice 5: Migration to native IPv6 scenario.

- Practice 6: Migration to scenario of coexistence with $\mathrm{IPv} 4$.

- Practice 7: Post transition management of IPv6.

The purpose, description, inputs and outputs of each of the seven practices are presented in what follows.

\section{Practice 1. Planning of the transition project}

Purpose: To formally commence the planning of the project of transition to IPv6.

Description: A project manager must be assigned and a project team established. In this practice, those who are interested in the transition are identified, the scope/outco$\mathrm{me} / \mathrm{goal}$ of the project is specified, the communication of the project to the wider community is planned, the principal activities are identified, an estimated schedule is defined and the human resources that will participate directly in the exe- la gestión de transición de servicios, la gestión del cambio y la gestión de la configuración.

Dada la definición de escenarios de migración, se determina si se realiza una transición total a IPv6 o si, por el contrario, se ejecuta una coexistencia de ambos protocolos (IPv4 e IPv6); se debe analizar cuál de los dos escenarios es el más adecuado para la organización. Sin embargo, para el último caso existe una premisa subyacente, la cual indica que toda la infraestructura debe ser implementada bajo IPv6 en el largo plazo. Por ende, es fundamental realizar un diagnóstico y un análisis detallado de dicha infraestructura.

\section{La guía propuesta}

La guía de buenas prácticas propuesta se basa en siete practicas ordenadas de manera secuencial y diseñadas con una plantilla con los siguientes aspectos: propósito, descripción, entradas, proceso (tecnológico, educacional y de dimensiones políticas), y salidas.

Las siguientes son las siete prácticas que componen la guía de buenas prácticas para la transición a IPv6:

- Práctica 1: Planeamiento de la transición del proyecto.

- Práctica 2: Definición de reglas.

- Práctica 3: Recolección de información.

- Práctica 4: Plan de implementación de la transición a IPv6.

- Práctica 5: Migración a un escenario IPv6 nativo.

- Práctica 6: Migración a un escenario con coexistencia IPv4.

- Práctica 7: Gestión post transición a IPv6.

El propósito, descripción, entradas y salidas de cada uno de las siete prácticas se presenta en los siguientes párrafos.

\section{Práctica 1. Planeamiento de la transición del proyecto}

Propósito: dar inicio formalmente a la planeación del proyecto de transición hacia IPv6.

Descripción: se debe asignar un gerente de proyectos y se debe conformar el equipo del proyecto. En esta práctica se identifica a aquellos interesados del proceso de transición y se especifica el alcance del proyecto, se planea la comunicación del proyecto a la comunidad organizacional, se identifican las principales actividades y un cronograma inicial, además del recurso humano que participará directamente en la ejecución de la transición. Es importante definir el alcance del proyecto teniendo en cuenta las restricciones (en términos de costo, tiempo, recursos humanos, etc.) que puedan ocurrir durante su ejecución.

Si la organización tiene una Oficina de Gestión de Proyectos [PMO, Project Management Office], debe considerarse la transición a IPv6 como un proyecto. Por ende, debería aplicarse la habitual metodología para la implementación de proyectos adoptada por la organización. Si dicha metodología no está definida, la organización debe utilizar una 
existente como la que presenta la guía del PMBOK (Project Management Book of Knowledge).

\section{Entradas:}

- Lista del personal del departamento de TI de la organización.

- Actas organizacionales, tanto del departamento de TI como de la organización en general.

- Metodología utilizada por la organización para la gestión de proyectos.

\section{Salidas:}

- Nombre del gerente de proyectos

- Lista del personal del departamento de TI que trabajará en el proyecto de transición

- Lista de servicios de TI de alto nivel

- Carta del proyecto

- Alcance del proyecto

- Otras salidas asociadas a las metodologías de la gestión de proyectos.

\section{Práctica 2 - Definición de reglas}

Propósito: definir las reglas que se adoptarán durante la transición hacia IPv6.

Descripción: después de la definición del gerente de proyectos, la conformación del equipo de proyecto y del alcance inicial del proceso de transición, es necesario definir las reglas para la adopción de la nueva versión del protocolo (IPv6) y su subsecuente operación.

Las reglas deben definir la adopción de IPv6 (junto con el soporte de gestión de alto nivel) y deben establecer metas (con fechas) para la culminación de la migración.

\section{Entradas:}

- Reglas establecidas por entidades gubernamentales en casos exitosos.

- Documentación, foros, grupos de investigación y artículos científicos acerca de IPv6.

- Plan inicial del proyecto de transición a IPv6.

\section{Salidas:}

- Reglas para la adopción de IPv6.

- Reglas para la capacitación en IPv6.

- Reglas para la operación con IPv6.

\section{Práctica 3 - Recolección de información}

Propósito: comprender el estado del arte en el área de TI y en los servicios e infraestructura disponibles en dicha área, con el fin de obtener una panorámica del estado actual de la tecnología en relación con el alcance definido en el proyecto.

Descripción: en esta práctica se obtiene información acerca de la infraestructura, las aplicaciones y el recurso humano que estará en el alcance del proceso de transición. Adicionalmente se utilizan técnicas para la recolección de cution of the transition are selected. It is important to define the scope of the project taking into account the restrictions (in terms of cost, time, etc.) that can appear along the way.

If the organization has a Project Management Office (PMO), the transition to IPv6 should be considered as a project and the habitual methodology for implementation of projects adopted by the organization should be applied to the transition. Otherwise, the organization should utilize an existing methodology such as the guide of PMPBok.

\section{Inputs:}

- A list of the personnel of the Information Technology department of the organization.

- Organizational charts of both the IT department and the organization as a whole.

- The methodology used by the organization for project management.

\section{Outputs:}

- The project manager's name.

- A list of IT department personnel who will work on the transition project.

- A list of IT services at a high level.

- The project letter.

- The defined scope of the project.

- Other outputs associated with the methodologies of project management.

\section{Practice 2. Definition of policies}

Purpose: To define the policies that will be adopted during the transition to IPv6.

Description: After having defined the project manager, the project team and the initial scope of the process of transition, it is necessary to define the policies for the adoption of the new version of the protocol (IPv6) and the subsequent operation with it.

The policies must define the adoption of IPv6 (with the wholehearted support of high-level management) and must establish goals (dates) for the completion of the migration.

\section{Inputs:}

- Policies established by national governments in successful cases.

- Documentation, forums, investigation groups, papers about IPv6 content.

- Initial plan of the project of transition to IPv6.

\section{Outputs:}

- Policies for the adoption of IPv6.

- Policies for training about IPv6.

- Policies for operation with IPv6. 


\section{Practice 3. Gathering of information}

Purpose: To comprehend the state of the art of the IT area and the services and infrastructure available to this area, to get a picture of the real state of technology in relation to the defined scope of the project.

Description: In this practice information is gathered about the infrastructure, the applications and the human resources that will be within the scope of the process of transition. Additionally, techniques for the gathering of information and the definition of the infrastructure according to the scope of the migration plan are utilized. It is important to take into account aspects of the environment of the infrastructure and the connectivity with service providers, employees, legacy systems, etc.

\section{Inputs:}

- Diagrams of the infrastructure.

- Diagrams of applications.

- Functional structure of the area.

- Connectivity maps.

- Tools for the gathering of inventory.

- Registers of technological inventory.

- A stakeholders matrix.

- Corporate policies concerning IPv6.

- Definition of the scope.

- Implementation guide for IPv6.

\section{Outputs:}

- Templates of technological inventory.

- Information about the profiles and the training needs of employees.

- Policies concerning legacy systems or other aspects found and defined in the process.

\section{Practice 4. Implementation plan of the transition to IPv6}

Purpose: Provide the technical information necessary for the implementation of the transition to IPv6.

Description: A detailed plan is created to execute the implementation of the transition based on an inventory of technological hardware and software. For each one, the following are defined: a priority, the date of implementation of the transition, the type of transition to implement (whether it is a total migration to IPv6 or a coexistence with $\mathrm{IPv}_{\mathrm{v}}$ ).

According to the quantity of technological hardware and software registered in the inventory and with an estimation of growth, it is possible to get an idea of the quantity of IPv6 addresses that need to be acquired from an Internet Service Provider (ISP). An addressing scheme of the organi- información y para la definición de la infraestructura de acuerdo con el alcance del plan de migración. Es importante tener en cuenta aspectos del ambiente de la infraestructura y de la conectividad con proveedores de servicio, empleados, sistemas heredados, etc.

\section{Entradas:}

- Diagramas de la infraestructura.

- Diagramas de aplicaciones.

- Estructura funcional del área.

- Mapas de conectividad.

- Herramientas para el inventario de la información recopilada.

- Registros de inventario tecnológico.

- Matriz de interesados.

- Reglas corporativas concernientes a IPv6.

- Definición del alcance.

- Guía de implementación para IPv6.

\section{Salidas:}

- Plantillas de inventario tecnológico.

- Información acerca de los perfiles y la capacitación necesaria para los empleados.

- Normas respecto a sistemas heredados u otros aspectos encontrados y definidos en el proceso.

Práctica 4 - Implementación del plan de la transición a IPv6

Propósito: proveer la información técnica necesaria para la implementación de la transición hacia IPv6.

Descripción: se crea un plan detallado para ejecutar la implementación de la transición basado en el inventario de hardware y software disponible, para estos elementos se define: la prioridad, la fecha de implementación de la transición y el tipo de transición a implementar (ya sea migración total hacia IPv6 o coexistencia con IPv4).

De acuerdo con la cantidad de hardware y software registrado en el inventario y con una estimación de su crecimiento, es posible obtener una idea de la cantidad de direcciones IPv6 que se necesitan adquirir del Proveedor de Servicios de Internet [ISP: Internet Service Provider]. Se debe diseñar un esquema de direccionamiento para la red de la organización, asignando subredes para enlaces punto a punto, retroalimentaciones y usuarios finales. Puesto que la transición hacia IPv6 es un cambio que afecta tanto el hardware como el software organizacional, las siguientes situaciones pueden llegar a aparecer durante la planeación:

- una organización que ha implementado el modelo

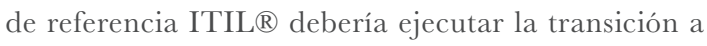
través de los procesos de gestión del cambio y gestión de la configuración;

- una organización que no haya implementado un marco de referencia debería utilizar herramientas 
software para almacenar la información del hardware y software inventariado y mantener dicha información actualizada, especialmente durante el proceso de transición.

\section{Entradas:}

- Inventario de hardware y software.

- Reglas acerca de la implementación de IPv6 (educación y tecnología).

- Investigación, cursos y capacitaciones asociadas con la tecnología IPv6.

\section{Salidas:}

- Plan para la implementación de la transición.

- Direccionamiento IPv6 o IPv4, de acuerdo con el alcance.

\section{Práctica 5 - Migración a un escenario IPv6 nativo}

Propósito: aplicar el proceso de implementación de la transición hacia un escenario IPv6 nativo en la infraestructura, de acuerdo con lo definido en el alcance.

Descripción: basado en la recolección de información discutida previamente, en esta práctica es conveniente utilizar las buenas prácticas de TI para la gestión del cambio y la gestión de la configuración. En esta práctica se podrían detectar los posibles riesgos asociados a la implementación de IPv6.

\section{Entradas:}

- Plan para la implementación de la transición.

- Esquema de direccionamiento IPv6.

\section{Salidas:}

- Reporte de la implementación de la transición.

- Reporte del plan de capacitación y su ejecución.

- Inventario del hardware y software.

- Reporte de las lecciones aprendidas en el proceso.

Práctica 6 - Migración hacia un escenario de coexistencia con IPv4

Propósito: aplicar el proceso de implementación de la transición hacia IPv6, pero manteniendo coexistencia con IPv4 en la infraestructura, de acuerdo con lo definido en el alcance.

Descripción: basado en la recolección de información previamente discutida, en esta práctica es conveniente utilizar las buenas prácticas de TI para la gestión del cambio y la gestión de la configuración. Es esencial actualizar el inventario y la configuración, donde existe un registro de los componentes en la infraestructura que no fue posible migrar a IPv6 permanentemente, por ejemplo, sistemas heredados.

\section{Entradas:}

- Plan para la implementación de la transición.

- Esquema de direccionamiento IPv6. zation's network should be designed, assigning sub-networks for point-to-point links, loopbacks and end-users. Given that the transition to IPv6 is a change that affects all the technological hardware and software, the following two situations can surface in the planning:

- An organization that has implemented the reference model ITIL should execute the transition through the processes of change management and configuration management.

- An organization that hasn't implemented a framework of reference should use a software tool to store the information of the technological hardware and software inventoried and keep this information up to date, especially during a process of transition.

\section{Inputs:}

- An inventory of technological hardware and software.

- Policies regarding the implementation of IPv6 (education and technology).

- Research, courses and training associated with IPv6 technology.

\section{Outputs:}

- A plan for the implementation of the transition.

- IPv6 or IPv4 addressing scheme, according to the scope.

Practice 5 - Migration to native IPv6 scenario

Purpose: To apply the process of implementation of the transition to native IPv6 in the infrastructure in accordance with the defined scope.

Description: Based on the gathering of information discussed previously, in this practice it is convenient to use the best practices of IT for the Change Management and Configuration Management. Possible risks associated with the implementation of IPv6 may be detected in this practice.

\section{Inputs:}

- A plan for the implementation of the transition.

- IPv6 addressing scheme.

\section{Outputs:}

- A report on the implementation of the transition.

- A report on the plan for training and its execution.

- An inventory of technological hardware and software.

- A report on the lessons learned from the process.

Practice 6 - Migration to scenario of coexistence with IPV4

Purpose: The objective of this practice is to apply the process of implementation of the transition to IPv6 while maintaining a coexistence with IPv4 in the infrastructure in accordance with the defined scope.

Description: Based on the gathering of information 
discussed previously, in this practice it is convenient to use the best practices of IT for the Change Management and Configuration Management. It is essential to update the inventory and configuration, where there is a record of the components of the infrastructure that didn't manage to migrate to IPv6 permanently, for example legacy systems.

\section{Inputs:}

- A plan for the implementation of the transition.

- IPv6 addressing scheme.

\section{Outputs:}

- A report on the implementation of the transition.

- A report on the plan for training and its execution.

- An inventory of technological hardware and software.

- A report on the lessons learned from the process.

Practice 7 - Post transition management of IPv6

Purpose: The objective of this practice is to provide recommendations for the operation of the technological hardware and software that will operate with IPv6.

Description: Once the transition to IPv6 is done, whether it is to native IPv6 or in a scenario of coexistence with IPv4, a methodology of operation should be established.

The state of each piece of technological hardware and software after migration should be known in a precise manner, i.e. its attributes or characteristics, among them the network protocol within which it operates.

The management of the infrastructure, applications and operating systems should be done via a reference framework such as ITIL for optimum and organized operation. If ITIL hasn't already been implemented in the organization, the recommendation is to implement this framework. Furthermore, the management of incidents, configuration and change should be done with technological tools that facilitate the administration of resources such as an addressing scheme and the storage of the inventory of technological hardware and software and their configurations.

The personnel should seek training in reference frameworks of best practices such as ITIL to manage the technological hardware and software and administer networks operating under IPv6.

Once the migration to IPv6 protocol has been executed, the organization, via the IT department, should establish policies that must be followed by all employees, providers of applications and other technology and all the other people or entities that have dealings with the organization.

\section{Salidas:}

- Reporte de la implementación de la transición.

- Reporte del plan de capacitación y su ejecución.

- Inventario del software y hardware.

- Reporte de las lecciones aprendidas en el proceso.

\section{Práctica 7 - Gestión de la post transición a IPv6}

Propósito: brindar recomendaciones para la operación del hardware y software que operará con IPv6.

Descripción: una vez la transición a IPv6 está completa, ya sea de manera nativa o en un escenario de coexistencia con IPv4, se debe establecer una metodología de operación, se debe conocer el estado de cada pieza de hardware y software después de la migración de manera precisa, esto es, sus atributos y características, además del protocolo de red que utiliza para operar.

La gestión de la infraestructura, aplicaciones y sistemas operativos debe realizarse a través de un marco de referencia como ITIL ${ }^{\circledR}$ para una operación óptima y organizada. Si ITIL ${ }^{\circledR}$ no ha sido implementado aún en la organización, la recomendación es implementar este marco de referencia. Además, la gestión de incidentes, la gestión de la configuración y la gestión del cambio deben realizarse con herramientas tecnológicas que faciliten la administración de recursos, tales como el esquema de direccionamiento y el almacenamiento de inventario de hardware y software (junto con sus respectivas configuraciones).

El personal debería ser capacitado en marcos de referencia de buenas prácticas como ITIL $\AA$, para gestionar el hardware y software y administrar la operación de las redes bajo IPv6.

Una vez la migración hacia IPv6 se ha ejecutado, la organización - a través del departamento de TI- se debe establecer políticas que deben cumplir todos los empleados, proveedores de aplicaciones y otro personal relacionado con dicho departamento, además del personal que tiene negocios con la organización.

\section{Entradas:}

- Reporte de la implementación de la transición.

- Inventario del hardware y software.

\section{Salidas:}

- Guía de buenas prácticas para la transición de servicios y aplicaciones de TI de una organización desde IPv4 hacia IPv6.

La Figura 1 muestra una ilustración de la guía de buenas prácticas para la transición hacia IPv6.

\section{Validación de la guía propuesta a través} de la opinión de expertos

La propuesta descrita en este documento fue validada por tres expertos, cuyos perfiles incluyen experticia técnica y de gestión en redes, quienes trabajan en áreas operativas de 


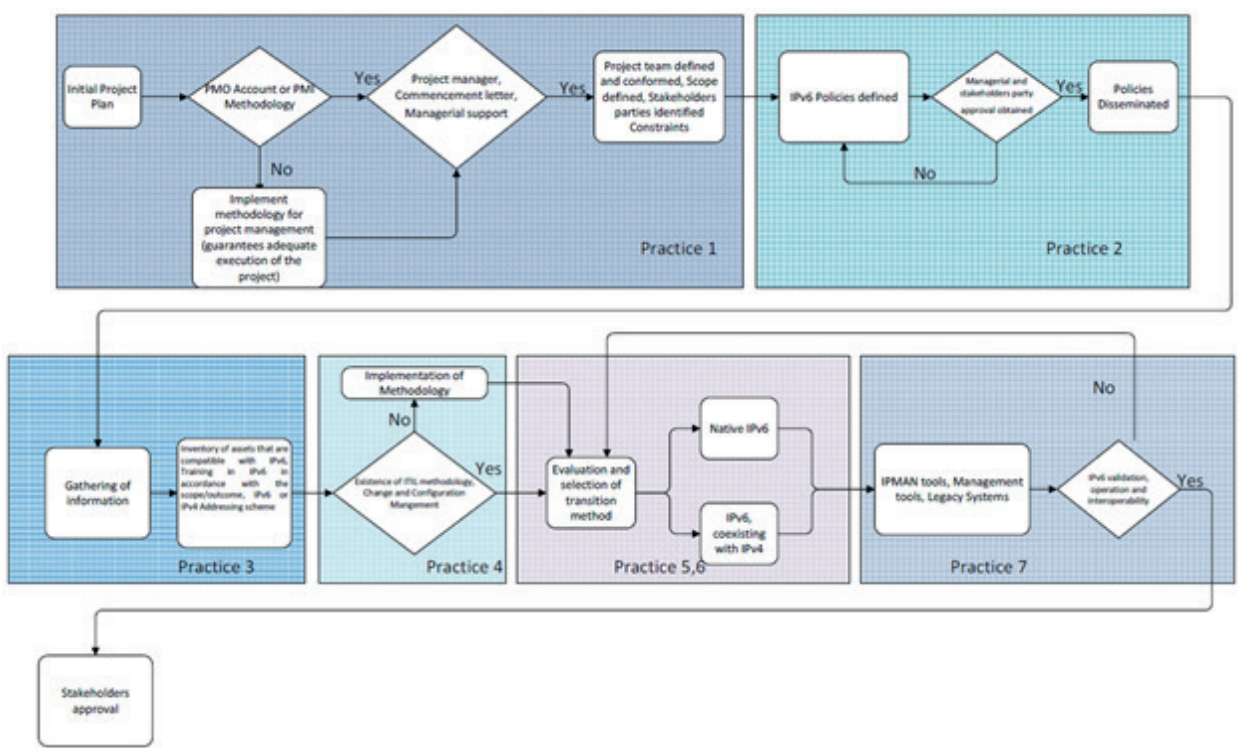

Figure 1. Guide of transition from IPv4 to IPv6 / Guía para la transición de IPv4 a IPv6

departamentos de TI de diversas compañías. La selección de expertos se basó en individuos con nivel de maestría y una vasta experiencia y conocimiento en TI e infraestructura de red.

La validación se hizo con base en cinco preguntas que debían ser calificadas con una escala de 1 (menor satisfacción) a 5 (mayor satisfacción). Cada experto validó: la consideración del problema, la aplicabilidad, la claridad, la oportunidad y la división de la guía. La Tabla 1 presenta los resultados obtenidos de la encuesta de validación completada por los tres expertos.

\section{Conclusiones y trabajo futuro}

La generación de políticas, tecnología y educación fueron identificadas como los aspectos fundamentales para la transición hacia IPv6, por ello, en esta guía, éstas fueron definidas como las dimensiones para cada una de las prácticas.

\section{Inputs:}

- A report on the implementation of the transition.

- An inventory of technological hardware and software.

\section{Outputs:}

- A guide to best practices for the transition of services and applications of the IT of an organization from IPv4 to IPv6.

Figure 1 shows an illustration of the guide to best practices for the transition to IPv6.

\section{Validation of the proposed gui- de through expert opinion}

The proposal was put forward for validation by three experts whose profile includes technical as well as ma-

Table 7. Grades given by experts for the models / Calificación de los expertos para los modelos

\begin{tabular}{lcl}
\hline Aspect / Aspecto & $\begin{array}{l}\text { Average score / } \\
\text { Puntaje promedio }\end{array}$ & Conclusions / Conclusiones \\
\hline $\begin{array}{l}\text { Consideration of the problem / Con- } \\
\text { sideración del problema }\end{array}$ & 5.00 & $\begin{array}{l}\text { The problem was well identified and put forward with clarity. / El } \\
\text { problema fue bien identificado y se propuso con clanidad. }\end{array}$ \\
\hline Applicability / Aplicabilidad & 4.67 & $\begin{array}{l}\text { The guide is viable and applicable in the IT area of an organization } \\
\text { to put into effect the transition from IPv4 to IPv6. / La guía es viable y aplica- } \\
\text { ble en el área de TI de una organización para materializar la transición de IPv4 a IPv6. }\end{array}$ \\
\hline Clarity / Clanidad & 5.00 & $\begin{array}{l}\text { The guide is clear and easy to comprehend. Every step is clearly exp- } \\
\text { lained. / La guía es clara y fácil de comprender, cada paso está claramente explicado. }\end{array}$ \\
\hline Opportunity / Oportunidad & 5.00 & $\begin{array}{l}\text { The guide is opportune because it is in accordance with the evolution } \\
\text { of technology and the state of the art in the Colombian medium. / La } \\
\text { guía es oportuna, presenta actividades relacionadas con la evolución de la tecnología y del estado del arte en } \\
\text { el medio colombiano. }\end{array}$ \\
\hline Division of the guide / División de la guía & $\begin{array}{l}\text { The guide's organization is adequate with seven practices logically } \\
\text { and sequentially ordered, starting with the planning phase and ending } \\
\text { with the post transition phase. / La organización de la guía es adecuada, con siete } \\
\text { prácticas ordenadas de manera lógicay secuencial, empezando con la fase de planeación y finalizando con } \\
\text { la fase de post-transición. }\end{array}$ \\
\hline
\end{tabular}


nagerial expertise, and who work in operative areas and Information Technology.

The selection of experts was based on individuals with a Master's degree and a long record of work experience, who have knowledge of Information Technology and network infrastructure.

The validation was done on the basis of five questions which could be rated from 1 to 5 . Each one validated an aspect: consideration of the problem, applicability, clarity, opportunity and division of the guide. TABLE 1 reveals the results obtained from the validation survey completed by the three experts.

\section{Conclusions and future work}

The generation of policies, technology and education were identified as the fundamental aspects for the transition to IPv6. Therefore, in the guide, these were defined as the dimensions for each of the practices.

In spite of the existence of various initiatives to support the process of transition towards IPv6, policies must be developed and disseminated by the government.

The planning and implementation of a high impact project such as the transition to IPv6 can be carried out successfully in an organization that has implemented a model of project management such as PMPBok and a reference framework of best practices of IT such as ITIL version 3 .

The guide proposed in this article for the transition to IPv6 was validated and approved by expert evaluators. Their opinions lead to the conclusion that the guide is clear, opportune and applicable.

This guide can be used as a reference for countries that are in the process of transition from $\mathrm{IPv}_{4} 4$ to $\mathrm{IPv} 6$ because it permits the complexity and the implications of such a project to be gauged. Sst
A pesar de la existencia de varias iniciativas para soportar el proceso de transición hacia IPv6, se deben desarrollar reglas y éstas deben ser diseminadas por los gobiernos.

La planeación e implementación de un proyecto de alto impacto, como la transición hacia IPv6, puede ejecutarse de manera satisfactoria en una organización que tenga implementado un modelo de gestión de proyectos - como el descrito en el PMBOK-y un marco de referencia de buenas prácticas de TI como ITIL® en su versión más reciente (versión 3).

La guía para la transición hacia IPv6 propuesta en este documento fue validada y aprobada por evaluadores expertos. Sus opiniones conllevan a la conclusión de que la guía es clara, oportuna y aplicable.

Esta guía puede utilizarse como referencia en los países en donde el proceso de transición de IPv4 a IPv6 esté en planeamiento o ejecución, puesto que permite evaluar este proyecto de transición, dada su complejidad e implicaciones. ST

\section{References / Referencias}

Cicileo, G., Gagliani, R., O'Flaherty, C., Olvera, C., Palet, J., Rocha, M., \& Vives, A. (2009). IPv6 Para Todos. Buenos Aires, Argentina: Internet Society. Available at https://nic.ar/static/files/ipv6paratodos.pdf

CIO Council. (2012). Planning guide/Roadmap toward IPv6 adoption within the U.S. Retrieved from: http://www.ipv6forum. com/dl/presentations/USGv6Roadmap.pdf

Gobierno de España / Ministerio de Industria, Energía y Turismo. (2011). Transición a IPv6: plan de fomento para la incorporación de IPv6 en España. Retrieved from: http://www.ipv6.es/es-ES/transicion/Paginas/Fomento.aspx

Internet Society of Australia (2009). IPv6 for business. North Sydney, Australia: Author.

Lacnic (2014). IPv6 Portal Lacnic [Web site]. Retrieved form: http://www.lacnic.net/web/lacnic/ipv6

Madera, L. \& Roa, M. (2014). Guía de buenas prácticas para la transición de IPV4 a IPV6 de los servicios y aplicaciones del área de tecnología de la información en una organización [thesis]. Universidad Icesi: Cali, Colombia.

Palet, J. (2011). Agotamiento de IPv4 o transición a tiempo a IPv6 para el adecuado crecimiento de la banda ancha. Available at: http://www.consulintel.es/pdf/ipv6_spain.pdf 


\section{CURRICULUM VITAE}

Lennart Enrique Madera Telematics Engineer (Universidad Icesi, Cali-Colombia), Specialist in Engineering Management Systems (Pontificia Universidad Javeriana, Cali-Colombia), Master in Informatics Management and Telecommunications (Universidad Icesi). Currently he is working with the Technology Area at Empresas Municipales de Cali [Emcali], an industrial and commercial state owned enterprise, responsible for provision of utilities (including telecommunications) in Cali / Ingeniero Telemático, Especialista en Sistemas Gerenciales de Ingenieria, Máster en Gestión Informática y Telecomunicaciones. Actualmente trabaja con la Gerencia de Tecnología de las Empresas Municipales de Cali [Emcali], empresa industrial y comercial del Estado, encargada del suministro de servicios públicos (incluyendo telecomunicaciones) en la ciudad de Cali.

Mario Alejandro Roaz Electronic Engineer (Universidad del Cauca, Popayán-Colombia), Master in Informatics Management and Telecommunications (Universidad Icesi, Cali-Colombia). Currently he is working for the Strategic Business Area of Telecommunications at Empresas Municipales de Cali [Emcali], an industrial and commercial state owned enterprise, responsible for provision of utilities (including telecommunications) in Cali / Ingeniero Electrónico de la Universidad del Cauca con Maestría en Gestión Informática y Telecomunicaciones de la Universidad Icesi. Actualmente trabaja con la Gerencia de la Unidad Estratégica del Negocio de Telecomunicaciones en las Empresas Municipales de Cali [Emcali], empresa industrial y comercial del Estado, encargada del suministro de servicios públicos (incluyendo telecomunicaciones) en la ciudad de Cali.

Juan C. Cuéllar Q. Ph.D in Telematics Student at the Universidad del Cauca (Popayán, Colombia). Electrical Engineer (Universidad del Valle, Cali-Colombia), and Specialist in Networks and Communications and Networks and Telematics Services (Universidad Icesi, Cali-Colombia), and Master in Engineering, emphasis in Telecommunications (Universidad Pontificia Bolivariana, Medellín-Colombia). Full time professor and Telematics Engineering Program Director at the Universidad Icesi / Estudiante del Doctorado en Telemática de la Universidad del Cauca. Ingeniero Electricista de la Universidad del Valle, con Especialización en Redes y Comunicaciones, y en Redes y Servicios Telemáticos de la Universidad Icesi, y Maestría en Ingeniería - Área Telecomunicaciones de la Universidad Pontificia Bolivariana. Es profesor de tiempo completo y Director del Programa de Ingeniería Telemática de la Universidad Icesi. 